\title{
Yanchang Group Tight Reservoir Study in Ordos Basin
}

\author{
Jingyi Wang ${ }^{1, a^{*}}$, Axiang Sun ${ }^{2, b}$, Lei Lv ${ }^{3, c}$ \\ ${ }^{1}$ Northeast Petroleum University, Daqing Heilongjiang China \\ ${ }^{2}$ Northeast Petroleum University, Daqing Heilongjiang China \\ ${ }^{3}$ Oil Testing and Perforating Company \\ a*525354060@qq.com, ${ }^{\mathrm{b}} 714854999 @ q q . c o m,{ }^{\mathrm{c}} 5738007 @ q q . c o m$
}

Keywords: Tight oil; Reservoir; Accumulation conditions; Ordos basin

\begin{abstract}
Yanchang group of southeastern Ordos basin are tight oil accumulation conditions of the research degree is low, the tight oil exploration has not obtained the big breakthrough. To evaluate tight oil exploration prospect of southeastern basin Yanchang group, through to the sedimentary, reservoir, cap rock, oil and gas migration, such as research, in-depth analysis of the southeastern basin Yanchang group tight oil accumulation conditions. Research results show that the southeastern basin reservoir density, source store is configured, has the good geological conditions of forming tight oil.Chang6,7,8 oil reservoir group are main tight oil exploration in southeastern Yanchang group of Ordos basin. Tight oil reservoir of the formation and enrichment of Yanchang group mainly controlled by sedimentary microfacies, the high quality reservoirs. Study shows that the tight oil reservoir main accumulation period to the early cretaceous, tight oil accumulation period under the control of the late Mesozoic tectonic thermal event, has the characteristics of late accumulation.
\end{abstract}

\section{Introduction}

In recent years, tight gas, tight oil, oil shale and other unconventional oil and gas resources in the United States, Canada, Australia and other countries have got the business development, now has an important role in the global energy structure. Tight sandstone gas, tight oil, oil shale and coal bed methane and other unconventional oil and gas resources of China is rich, but the exploration and development is still at the preliminary and exploratory stage [1]. Reservoir of Yanchang group in Ordos basin low maturity, strong diagenesis, rock particles, poor sorting and high cement content, large reservoir space variation, strong heterogeneity, Reservoir presents reservoir density, forecasting is difficult, complex reservoiring mechanism, single well production is not high, is a typical low permeability reservoir development area in China [2]. Among them, the tight oil and gas resources is rich, has huge potential of exploration and development, has now become an important field of oil and gas exploration and development of Ordos basin, strengthen the tight oil research of Ordos basin, for China's tight oil resources is of great significance to the exploration and development [3].

Ordos basin is rich in oil and gas resources, Yanchang group as the most important hydrocarbon source rock development degree and hydrocarbon reservoir in Mesozoic of basin. Yanchang group of oil and gas exploration in recent years have great advancements, found more of the low permeability -ultra-low permeability (mostly tight sandstone oilfield )in Yanchang group, the exploration and development of tight oil and research important progress has been made. 


\section{Geological survey}

The general situation in the study area. The north of Ordos basin Is bounded in Yin Mountain and the Daqing Mountain and Wolf mountain, south to Qinling Mountains, the east side to the lvliang mountains, with a total area of $0.32 \times 106 \mathrm{~km} 2$ [4].Its geotectonic position is in the west of north China platform, is in craton marginal depression basin, is the main large Mesozoic basins in China, is composed of six first-order tectonic units:Yimeng swell,Weibei swell,Jinxi flexure belt, Yisha slope, Tianhuan depression, Xiyuan thrust tectonic belt.

The regional geological structure and formation characteristics. Ordos basin in the process of development, has experienced several tectonic movement, Affected by Indosinian yanshan movement in Mesozoic, developed a set of terrigenous clastic sedimentary strata. Among them, Triassic Yanchang group is a set of inland lake delta clastic sediments. Triassic Yanchang group

( T3y) is the first set of reservoir rock series after Ordos basin inland lake basin formation.,it is also the main formation of prospectingof basin [5]. The main lithology is a set of cyclicity deposits which is mainly composed of sage green, gray medium-thick massive fine sandstone、 siltstone and dark gray, gray black mudstone.

Ordos basin Yanchang group is a complete water into-water out sedimentary cycle. Late Triassic Yanchang period of Ordos basin is a large inland lake basin.Lake basin, opening to the southeast, southeast connected with big basin of north China. Ordos basin uplift as a whole At the end of Yanchang period, by regional erosion [6]. The middle of Yanshan cycle in Late Jurassic, eastern basin uplift, missing most of the late Jurassic sedimentary basin,only deposited the Upper Jurassic Fenfanghe formation in the western basin.After the end of Early Crataceous, Ordos basin uplift as a whole, the basin began to enter the uplift reconstruction period.

\section{The distribution of oil Ordos basins}

Ordos basin Mesozoic Yanchang group of tight oil resources is rich [7,8].The tight oil of Yanchang group distributed in the "core area" of the oil system: in the plane, is located in the middle of the lake basin, within the scope of the framed of Huanxian-Wuqi-Zhidan-Zhengning-

Ningxian-Qingyang,that is the sedimentary center of middle-late Triassic; On the longitudinal, located in the central part of Yanchang group layer, that is in the Dense sandstone reservoir which is interbed symbiosis with shale or close to it,oil without large-scale long-distance migration, reservoir are mainly delta front and front delta deposits, mainly fine sandstone, locally developed a fine sandstone; In central lake basin mainly for gravity flow deposits, mainly fine sandstone and siltstone, reservoir particularly tight, air permeability is generally less than $0.3 \times 10-3 \mu \mathrm{m} 2$.

\section{Analysis of the reservoir}

Yanchang group reservoir distribution area is large, from the point of view of depositional systems, there are northeast delta sandstone reservoir is controlled by the northeast provenance, and fan delta, delta sandstone reservoir is controlled by the southwest provenance[9].

Analysis of reservoir characteristics. Triassic reservoir rock are mainly terrigenous clastic rocks. In Triassic period, the overall for north east into the direction of the source, broad development of the various types of sand body. according to sedimentary system evolution study Yanchang group sedimentary period, due to differences in south and north tectonic activities, caused the basin is lower in the south and higher in the north, slope gentle ancient landform landscape in whole,in 
addition to the north east, north west two sediment sources, from the north axis material source as the main body[10]. The source on the edge of the lake basin developed a large delta depositional system, delta plain, delta front and front delta subfacies, boundaries clear. $T$ These sedimentary subfacies of channel sand body, mouth bar, far sand dam, front sheet sand sedimentary sand body development, Vertically superimposed each other, at the same time various types of sand body lateral coalesced, constitute the main body of the reservoir.

Diagenesis study. Vitrinite reflectance data show that Yanchang group sandstone has reached maturity. Main diagenesis includes: mechanical compaction, cementation, clay adsorption and dissolution[11]. The first three effect is unfavorable for the preservation of the pore, especially in the compaction and cementation. They are on the basis of the sedimentation, formed two types of low permeability reservoir sand body of Yanchang group.

Compaction of low permeability sandstone reservoir is the low permeability sandstone reservoir that due to mechanical compaction, the sandstone pore loss is mainly caused by compaction [12].The low permeability of Compaction-cementation developed in the delta plain distributary channel sand body and delta front sand body, this kind of sandstone pore loss is caused by mechanical compaction and cementation.

Analyzing the key factors affecting the reservoir. For the enrichment of tight oil reservoir,physical property is the main control function, usually space distribution of sand body and the plane distribution of reservoir property is consistency, usually in the shape, thickness of sand body, wide distribution area, are also the reservoir porosity, permeability value higher area, its oil content is generally good also.

Dissolution development or not is an important factor of reservoir pore development. In the middle of diagenetic stage, with the organic matter into oil threshold, the amount of $\mathrm{CO} 2$ that kerogen thermal evolution releaseed decreases the formation water $\mathrm{pH}$ value, make the formation water acidic.Terrigenous clastic carbonate, unstable feldspar and volcanic debris components of Sand body and parts of acid soluble cement, Become the object of underground acidic water dissolution in the middle of diagenetic stage, thus forming the secondary pore. A large number of the existence of dissolution pores, greatly improve the reservoir property.

\section{Conclusions}

The tight oil reservoir sand body distribution is stable of Ordos basin Yanchang group in Mesozoic, large reservoir scale; Dense sandstone reservoir, complex pore structure; Rigid component content is higher, natural fracture development; Sandstone reservoir has good reservoir conditions, the uplift and denudation of this for a long time in the late Triassic, the formation of the first secondary pores development zone under the affected by atmospheric fresh water leaching ; In the late of Triassic,organic thermal evolution accelerate the generation of secondary porosity, providing a space for the oil and gas reservoir.

High-quality hydrocarbon source rocks in southeastern area distribution, the distribution of tight oil mainly by sedimentary microfacies, reservoir property control.Reservoir property is the key to tight oil enrichment, high yield of Triassic Yanchang group. The distribution of dense oil in Southeastern of Ordos mainly controlled by sedimentary microfacies and reservoir physical property, reservoir physical property is the most key factors, Cracks on the improvement of the reservoir physical property have important influence. 


\section{References}

[1] Guo Yanru, Liu Junbang, Yang Hua, et al. Hydrocarbon accumulation mechanism of low permeable tight lithologic oil reservoirs in the Yan-chang Formation, Ordos Basin, China[J]. Petroleum Exploration and Development, 2012, 39(4) : 417-424.

[2] Li Wenhou, Pang Jungang, Cao Hongxia, et al. Depositional system and paleogeographic evolution of the late Triassic Yanchang Stage in Ordos Basin[J]. Journal of Northwest University, 2009, 39 (3):501-506.

[3] Yang Hua, $\mathrm{Fu}$ Jinhua, He Haiqing, et al. Formation and distribution of large low-permeability lithologic oil regions in Huaqing, Ordos Ba-sin[J]. Petroleum Exploration and Development, 2012, 39 (6) :641-648.

[4] Yang Hua, Li Shixiang, Liu Xianyang. Characteristics and resource prospects of tight oil and shale oil in Ordos basin[J]. Acta Petrolei Sinica, 2013, 34(1):1-11.

[5] Zou Caineng, Zhu Rukai, Wu Songtao, et al. Types, characteristics, genesis and prospects of conventional and unconventional hydrocar-bon accumulations: taking tight oil and tight gas in China as an in-stance[J]. Acta Petrolei Sinica, 2012, 33( 2) : 173-185.

[6] Niu Xiaobing, Feng Shengbin, Liu Fei, et al. Microscopic occurren ceof oil in tight sandstones and its relation with oil sources - a case study from the Upper Triassic Yanchang group, Ordos Basin [J] . Oil \& Gas Geology, 2013, 34( 3) : 288-293.

[7] Zhang Wenzheng, Yang Hua, Li Jianfeng, et al. Leading effect of high-class source rock of Chang 7 in Ordos Basin on enrichment of low permeability oil-gas accumulation: hydrocarbon generation and expulsion mechanism[J]. Petroleum Exploration and Development, 2006, 33( 3) : 289-293.

[8] Deng Xiuqin, Liu Xinshe, Li Shixiang. The relationship between com-pacting history and hydrocarbon accumulating history of the super-low permeability reservoirs in the Triassic Yanchang group in the Or-dos Basin[J]. Oil \& Gas Geology, 2009, 30(2): 156-161.

[9]Li Hong, Liu Yiqun.Reservoir geology model of lithological reservoir with low permeability in Xifeng Oilfield, Ordos Basin[J].Acta Sedimentologica Sinica, 2007, 25(6): 954-960.

[10] McBride E F.Diagenesis of the Maxon Sandstone (Early Cretaceous),Marathon region , Texas :A diagenetic quartzarenite [J]. Journal of Sedimentary Petroloty ,1987 , 57 (1):98-107.

[11] Baker J C, Havcrd P J, Martin K R.et al. Diagenesis and petro-physics cf the early Permian moogooloo sandstone, southern Carnarvon basin ,western Australian[J].AAPG Bullctin,2000, $84(2): 250-265$.

[12]Yu Jian,Yang Yajuan,Du Jinliang. Sedimentation during the transgressionperiod in Late Triassic Yanchang Formation, Ordos Basin[J].Petroleum Exploration and Development, 2010, 37(2): $181-187$. 